\title{
Mouse to human comparative genetics reveals a novel immunoglobulin E-controlling locus on Hsa8q12
}

\author{
Elena S. Gusareva • Helena Havelková • \\ Hana Blažková • Marcela Kosařová • Petr Kučera • \\ Vlastimil Král • Daria Salyakina • \\ Bertram Müller-Myhsok • Marie Lipoldová
}

Received: 29 May 2008 / Accepted: 23 October 2008 / Published online: 18 November 2008

(C) The Author(s) 2008. This article is published with open access at Springerlink.com

\begin{abstract}
Atopy is a predisposition to hyperproduction of immunoglobulin E (IgE) against common environmental allergens. It is often associated with development of allergic diseases such as asthma, rhinitis, and dermatitis. Production of $\operatorname{IgE}$ is influenced by genetic and environmental factors. In spite of progress in the study of heredity of atopy, the genetic mechanisms of $\mathrm{IgE}$ regulation have not yet been
\end{abstract}

Electronic supplementary material The online version of this article (doi:10.1007/s00251-008-0343-x) contains supplementary material, which is available to authorized users.

E. S. Gusareva · H. Havelková · H. Blažková · M. Kosařová •

M. Lipoldová $(\varangle)$

Department of Molecular and Cellular Immunology,

Institute of Molecular Genetics,

Academy of Sciences of the Czech Republic,

Vídeňská 1083,

14220 Prague 4, Czech Republic

e-mail: lipoldova@img.cas.cz

P. Kučera $\cdot$ M. Lipoldová

Third Faculty of Medicine, Charles University,

Ruská 87,

10000 Prague 10, Czech Republic

P. Kučera

Department of Allergology and Clinical Immunology,

University Hospital KV,

Šrobárova 50,

10034 Praha 10 Prague, Czech Republic

\section{Král}

Department of Immunology and Microbiology, Institute of Public Health,

Moskevská 15, P.O. Box 115, 40001 Ústí nad Labem,

Czech Republic

D. Salyakina $\cdot$ B. Müller-Myhsok

Max-Planck Institute of Psychiatry,

Kraepelinstrasse 2-10,

80336 Munich, Germany completely elucidated. The analysis of complex traits can benefit considerably from integration of human and mouse genetics. Previously, we mapped a mouse IgE-controlling locus $\operatorname{Lmr} 9$ on chromosome 4 to a segment of $<9 \mathrm{Mb}$. In this study, we tested levels of total IgE and 25 specific IgEs against inhalant and food allergens in 67 Czech atopic families. In the position homologous to $\operatorname{Lmr} 9$ on chromosome $8 \mathrm{q} 12$ marked by D8S285, we demonstrated a novel human IgE-controlling locus exhibiting suggestive linkage to composite inhalant allergic sensitization (limit of detection, $\mathrm{LOD}=2.11, P=0.0009)$ and to nine specific IgEs, with maximum $\mathrm{LOD}(\mathrm{LOD}=2.42, P=0.0004)$ to plantain. We also tested 16 markers at previously reported chromosomal regions of atopy. Linkage to plant allergens exceeding the LOD $>2.0$ was detected at $5 \mathrm{q} 33$ (D5S1507, $\mathrm{LOD}=2.11, P=0.0009)$ and $13 \mathrm{q} 14$ (D13S165, $\mathrm{LOD}=2.74$, $P=0.0002)$. The significant association with plant allergens (quantitative and discrete traits) was found at $7 \mathrm{p} 14$ (D7S2250, corrected $P=0.026$ ) and 12q13 (D12S1298, corrected $P=0.043$ ). Thus, the finding of linkage on chromosome $8 \mathrm{q} 12$ shows precision and predictive power of mouse models in the investigation of complex traits in humans. Our results also confirm the role of loci at $5 \mathrm{q} 33$, $7 \mathrm{p} 14,12 \mathrm{q} 14$, and 13q13 in control of IgE.

Keywords Atopy · Specific IgE - Genetic loci · Mouse-human homology $\cdot$ Czech population $\cdot 8 \mathrm{q} 12$

\section{Introduction}

Atopy is a complex trait characterized by predisposition to hyperproduction of immunoglobulin E (IgE) against common environmental allergens. It is a major risk factor for the development of allergic diseases such as asthma, 
rhinitis, and dermatitis. The susceptibility to atopic diseases has an important hereditary component. In the past 12 years, a number of genome-wide studies of atopy in humans identified several IgE-controlling loci and genes on different chromosomes (reviewed in Ober and Hoffjan 2006; Vercelli 2008). Some of these genes or loci were found to regulate susceptibility to atopic diseases in several populations, whereas others have been detected in one or a few populations only (reviewed in Ober and Hoffjan 2006). These controlling loci in most cases contain a number of genes, and it is not known which of them is responsible for the observed effects. It was suggested that in different populations, different genes from the same chromosomal region may be involved in control of susceptibility (reviewed in Ober and Hoffjan 2006; Zhang et al. 2008).

The most often detected linkages were to chromosomal regions 5q (Xu et al. 2000; Yokouchi et al. 2000, 2002; Haagerup et al. 2002; Koppelman et al. 2002), 6p (Daniels et al. 1996; Wjst et al. 1999; Haagerup et al. 2002; Fereira et al. 2005), 7p (Daniels et al. 1996; Laitinen et al. 2001; Shugart et al. 2001; Altmüller et al. 2005), 7q (Xu et al. 2000; Koppelman et al. 2002; Altmüller et al. 2005), 11q (Daniels et al. 1996; Shugart et al. 2001; Altmüller et al. 2005), 12q (Xu et al. 2000; Koppelman et al. 2002; Yokouchi et al. 2002), and 16q (Daniels et al. 1996; Ober et al. 2000; Kurz et al. 2005). Positional cloning indicated six genes at loci 2q14 (DPP10 - dipeptidyl serine protease; Allen et al. 2003), 2q33 (CTLA4-cytotoxic T-lymphocyteassociated-4 gene; Howard et al. 2002), 5q32-33 (PCDH1protocadherin-1; Whittaker 2003), 7p14.3 (GPRA - G-proteincoupled receptor; Laitinen et al. 2004), 13q14 (PHF11-PHD finger protein 11; Zhang et al. 2003), and 20p13 (ADAM33Zn-dependent metalloproteinase; van Eerdewegh et al. 2002) predisposing for atopy or atopy-associated traits. Genomewide association mapping led to the identification of the genes ORMDL3 (an endoplasmic reticulum membrane protein) at locus 17q21 (Moffatt et al. 2007) and CHI3L1 (chitinase 3like 1) at locus 1q32.1 (Ober et al. 2008) that contribute to the risk of asthma.

Despite this remarkable progress in the identification of genes controlling atopy and asthma in humans, the complete elucidation of its genetics is hindered by many factors including sample size, genetic heterogeneity of human populations, gene interactions, low frequency and/ or incomplete penentrance of trait-controlling alleles, and a high variability of environmental factors (Lander and Schork 1994).

Some limitations of human genetic studies could be overcome by the use of mouse models. The availability of genetically homogenous mouse strains and possibility of testing large numbers of $\mathrm{F}_{2}$ and backcross mice in a controlled environment that reduces the phenotypic variance makes the mouse a useful model for study of the complex traits in human (Lipoldová and Demant 2006). Once the genetic regions of interest have been identified in mouse, the high level of synteny between many mouse and human chromosomal segments allows predicting their locations in human (DeBry and Seldin 1996). A mouse model has been successfully applied for the identification of human homologues of mouse asthma genes Tim1 and Tim 3 in Tapr (an airway hyperreactivity regulatory) locus at chromosomes 5q33.2 and 5q33.3, respectively (McIntire et al. 2001).

In our previous genome-wide search performed in mouse, we described nine genetic loci on chromosomes 1 , 2, 3, 4, 5, 8, 10, 16, and 18 that control IgE level (Lipoldová et al. 2000; Badalová et al. 2002). This search did not target certain genes throughout the genome, but a set of genetic regions of total length of about $360 \mathrm{Mb}$. These regions are distributed randomly in the tested recombinant congenic (RC) strains. It must be emphasized that this occurred without any previous selection and without any prior knowledge about the gene content of these regions. The description of the principle of construction of RC strains is described in Demant and Hart (1986) and Lipoldová and Demant (2006). Subsequently, we used the homology between genetic maps of mouse and human to identify the corresponding orthologous regions on human chromosomes and found that the loci Lmr3, Lmr5, Lmr8, Lmr10, Lmr11, Lmr13, and Lmr14 (Lipoldová et al. 2000; Badalová et al. 2002) are located in the regions homologous with the human chromosomal segments known to control serum IgE in human atopic diseases (Wjst et al. 1999; Dizier et al. 2000; Xu at al. 2000, 2001; Yokouchi et al. 2000, 2002; Koppelman et al. 2002), indicating a likely relatedness of IgE-controlling genes in the two species. However, for two loci ( $L m r 9$ and Lmr12; Badalová et al. 2002) described by us, the homologous human regions have not been connected with atopy. These two loci may point to hitherto undetected human genes that are relevant for atopy. As Lmr 12 maps to a broad segment, we used for further study the locus Lmr9, which is rather precisely mapped to a segment with the most likely length of $3.58 \mathrm{Mb}$ and maximal possible length of $9.32 \mathrm{Mb}$ on chromosome 4 in the strain CcS-20. The mice homozygous for $\mathrm{BALB} / \mathrm{c}$ (high IgE responder) and STS/A (low $\operatorname{IgE}$ responder) alleles at this locus differed 1.6 times in $\operatorname{IgE}$ level (corrected $P$ value 0.00313; Badalová et al. 2002). In the orthologous region on human chromosome $8 \mathrm{q} 12$, we selected three short tandem repeat (STR) markers, D8S1828 (56.96 Mb), D8S285 (57.22 Mb), and D8S1816 (57.52 Mb; Fig. 1), and tested their non-parametric linkage and association (quantitative and discrete traits, QTDT) with inhalant and food atopy and with levels of total $\operatorname{IgE}$ and specific IgEs to 20 inhalant and five food allergens in the 67 Czech atopic nuclear families comprising 276 subjects. In order to define other loci that may control $\operatorname{IgE}$ 


\section{Mus musculus}

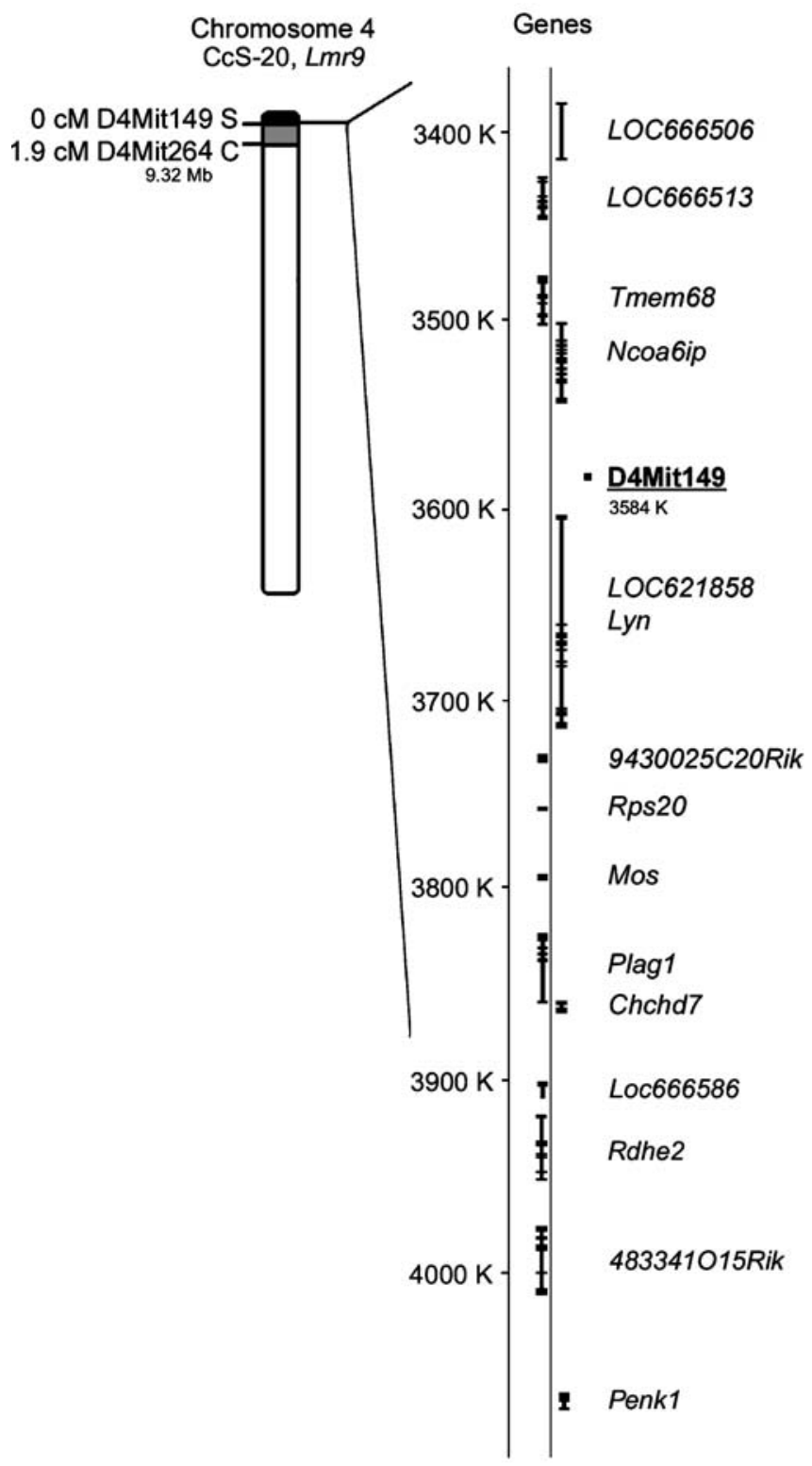

Fig. 1 Conserved synteny between the mouse and human genome regions. The region on recombinant mouse chromosome 4 ( $\mathrm{Lmr} 9$ locus) is homologous to the region on human chromosome $8 \mathrm{q} 12$. In the mouse chromosomal map, the segments of $\mathrm{BALB} / \mathrm{c}$ origin, where the Lmr9 locus is excluded, is marked open. The segment of STS origin, containing the $L m r 9$ gene, is marked closed. The gray segment indicates region of undetermined origin. The most likely and the maximal lengths of Lmr9 locus in mouse are 3.58 and $9.32 \mathrm{Mb}$, respectively. The $530 \mathrm{~Kb}$ region shown in detail encompasses genes in

in Czech atopic patients, we also selected markers in additional 16 candidate chromosomal regions for linkage and association testing with the atopic phenotypes (Table 1). These additional regions were previously shown to be linked or associated with atopy and/or asthma (Daniels et al. 1996; Wjst et al. 1999; Ober et al. 2000; Xu et al. 2000; Yokouchi et al. 2000, 2002; Laitinen et al. 2001;
Homo sapiens

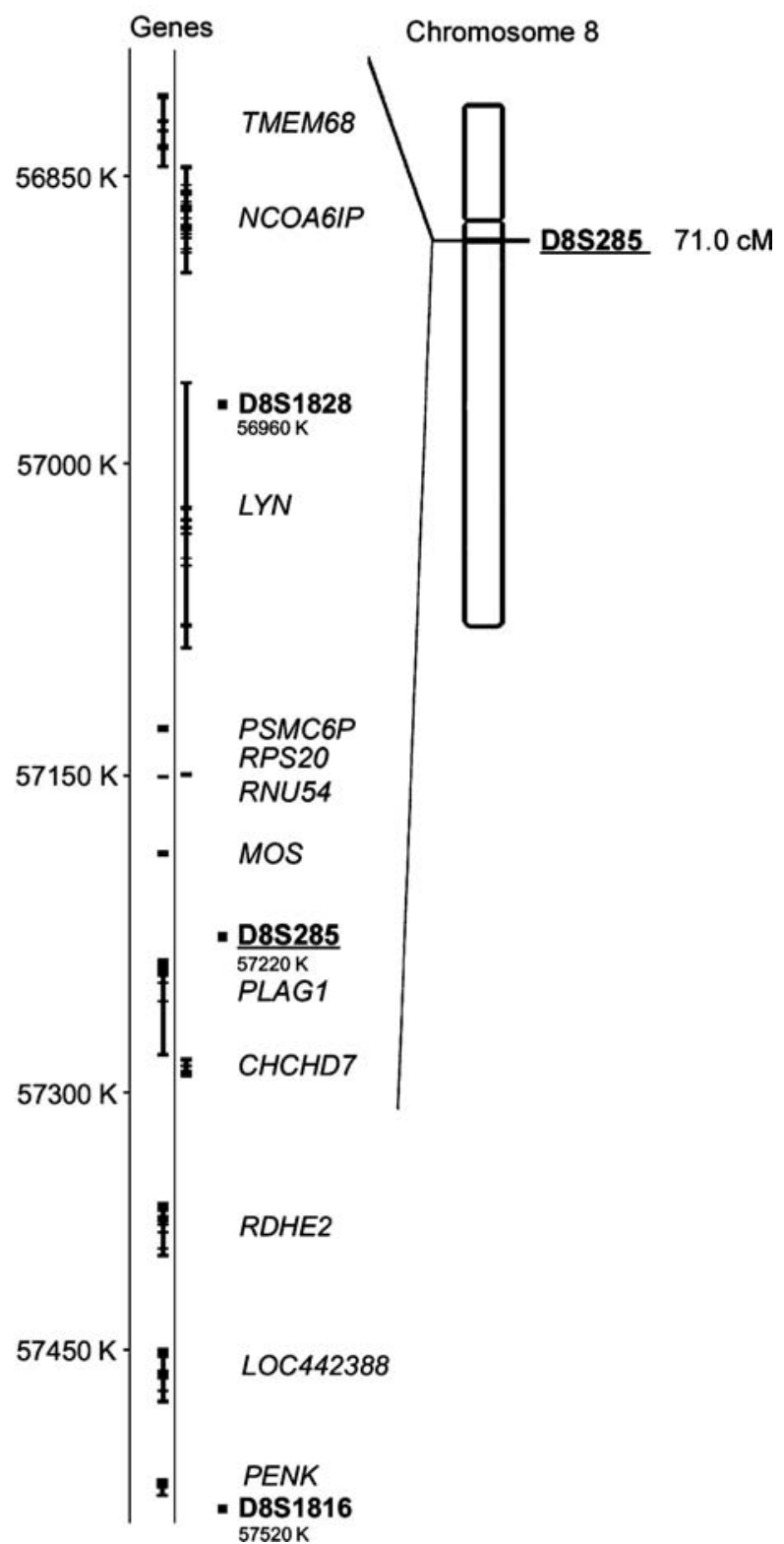

the close vicinity of the marker D4Mit149. The position of the marker is given as $0 \mathrm{cM}$ because it has not yet been separated from the centromere by recombination (http://www.informatics.jax.org/, August $25,2008)$. The markers in the segment on human chromosome 8 were selected so that one is located in the center of the $\pm 5 \mathrm{Mb}$ region orthologous to $\operatorname{Lmr} 9$ (D8S285) and the two other markers are approximately equidistant centromerically (D8S1828, $260 \mathrm{~kb}$ ) and telomerically (D8S1816, distance 300 kb; NCBI Homology Maps page—http://www.ncbi.nlm.nih.gov/projects/homology/maps/)

Shugart at al. 2001; Haagerup at al. 2002; Koppelman et al. 2002; van Eerdewegh et al. 2002; Allen et al. 2003; Altmüller et al. 2005; Ferreira at al. 2005; Kurz et al. 2005).

Hence, in the present study, instead of performing total genome scans in the analyzed families, we tested only the markers in the chromosomal regions that were either previously shown to define linkages in humans or repre- 
Table 1 List of markers tested for linkage and association with asthma, rhinitis and dermatitis, total $\operatorname{IgE}$, and specific IgE to 20 inhalant and five food allergens

\begin{tabular}{llll}
\hline Marker & Chromosome $^{\mathrm{a}}$ & $\mathrm{cM}$ (Marshfield) & Reference \\
\hline D2S308 & $2 \mathrm{q} 14.3$ & 124.03 & Allen et al. 2003 \\
D5S816 & $5 \mathrm{q} 31.1$ & 139.33 & Koppelman et al. 2002 \\
D5S1507 & $5 \mathrm{q} 33.3$ & 157.57 & Yokouchi et al. 2000 \\
D6S291 & $6 \mathrm{p} 21$ & 49.50 & Wjst et al. 1999 \\
D7S2250 & $7 \mathrm{p} 14.1$ & 54.11 & Daniels et al. 1996; Shugartt et al. 2001; Laitinen et al. 2001 \\
D7S821 & $7 \mathrm{q} 22.1$ & 109.12 & Xu et al. 2000 \\
D8S1828 & $8 \mathrm{q} 12$ & 71.00 & Badalová et al. 2002 \\
D8S285 & $8 \mathrm{q} 12$ & 71.00 & Badalová et al. 2002 \\
D8S1816 & $8 \mathrm{q} 12$ & 71.00 & Badalová et al. 2002 \\
D11S2006 & $11 \mathrm{q} 12$ & 59.24 & Adra et al. 1999 \\
D12S1298 & $12 \mathrm{q} 13$ & Barnes et al. 1996 \\
D12S379 & $12 \mathrm{q} 21.31$ & 95.17 & Nickel et al. 1997 \\
D12S1059 & $12 \mathrm{q} 22$ & Barnes et al. 1996 \\
D12S1282 & $12 \mathrm{q} 24.31$ & 105.18 & Barnes et al. 1996 \\
D13S165 & $13 \mathrm{q} 14$ & 136.82 & Zhang et al. 2003 \\
D16S3253 & $16 \mathrm{q} 21$ & 45.55 & Daniels et al. 1996 \\
D16S539 & $16 \mathrm{q} 23.2$ & 71.77 & Ober et al. 2000 \\
D19S601 & $19 \mathrm{q} 13.32$ & 124.73 & Venanzi et al. 2001 \\
D20S473 & 20p13 & 83.19 & Van Eerdewegh et al. 2002 \\
\hline
\end{tabular}

${ }^{a}$ The chromosomal regions were found in the GDB Human Genome Database (http://www.gdb.org, May 23, 2008)

sentative markers in the human chromosomal region that is homologous to the mouse $\operatorname{Lmr} 9$ locus that controls $\operatorname{IgE}$ levels (Table 1).

\section{Materials and methods}

Subjects and families

Nuclear families from the Czech Republic (67 families, $n=276$ ) originated from Prague (47 families, $n=192)$ and from towns Ústí nad Labem, Teplice and Most (13 families, $n=55$ ) and Trutnov ( 7 families, $n=29$ ), all located within less than $120 \mathrm{~km}$ from Prague. The families were collected through probands registered in local clinics as patients with a medical history of atopic disease. All available families were recruited into the study with the exception of $8 \%$ of families, which declined to participate for different reasons. The probands were not ascertained for another disorder.

The 67 nuclear atopic families contained 276 subjects, 138 of whom were offspring (Table 2, Electronic supplementary material Table 1). There was no stated relatedness between families. The mean and median age of the parents were 43.4 and 42.0 years, respectively, and that of the offspring were 15.9 and 14.0 , respectively. The sex ratio of the offspring was $0.53: 0.47$ (male to female). The percentage of the allergen-sensitized subjects among parents was $84.8 \%$ and among offspring $87.7 \%$.
All participants (offspring and spouses) have undergone clinical examination under the protocol approved by the Ethical Committee of the Third Faculty of Medicine, Charles University, Prague, Czech Republic. A full explanation of the study design was given to all participants, and subsequently, a written consent was obtained. Clinical specialists performed a structured interview with each participant (or his/her guardians), verified or newly established the diagnosis of asthma, rhinitis, dermatitis, conjunctivitis and/or urticaria according to EAACI guidelines (Johansson et al. 2001), and completed a questionnaire about the disease manifestations and smoking status.

\section{Estimation of total and specific IgE levels}

The collection of blood samples was conducted from February 1999 to February 2001. No blood samples were collected during the summer months. The sera were stored at $-70^{\circ} \mathrm{C}$ before use. The total $\operatorname{IgE}$ level was estimated in by CAP-FEIA (Pharmacia, Uppsala, Sweden). Specific IgE was measured by the in vitro test system EUROLINE (EUROIMMUN, Medizinische Labordiagnostika GmbH, Lübeck, Germany) according to the instructions of the manufacturer. In this system, allergen extracts were used for the detection of specific IgEs. The lowest threshold of detection was $0.35 \mathrm{kU} / 1$. We have tested 20 inhalant and five food allergens. Sensitization to moulds (m6-Alternaria alternata, m3-Aspergillus fumigatus, m2-Cladosporium 
Table 2 Characteristics of group of 276 participants from 67 families

\begin{tabular}{|c|c|}
\hline Group characteristics & Number $(\%)$ \\
\hline Nuclear atopic families & 67 \\
\hline Subjects & 276 \\
\hline Parents & 138 \\
\hline Age, mean $\pm \mathrm{SD}$, median & $43.4 \pm 10.7,42.0$ \\
\hline Smokers among parents, $n(\%)$ & $9(6.5 \%)$ \\
\hline Total $\operatorname{IgE}>100 \mathrm{kU} / 1, n(\%)$ & $60(43.5 \%)$ \\
\hline Parents with inhalant allergic sensitization & $112(81.2 \%)$ \\
\hline Food-sensitized parents & $52(37.7 \%)$ \\
\hline Parents with allergic asthma & $27(19.6 \%)$ \\
\hline Parents with allergic rhinitis & $69(50 \%)$ \\
\hline Parents with atopic dermatitis & $14(10.1 \%)$ \\
\hline Offspring/Children & 138 \\
\hline Age, mean $\pm \mathrm{SD}$, median & $15.9 \pm 8.53,14.0$ \\
\hline Sex, male/female & 0.53:0.47 \\
\hline Smokers among children, $n(\%)$ & 0 \\
\hline Children with total $\mathrm{IgE} \geq 100 \mathrm{kU} / 1$ & $89(64.5 \%$ of all children $)$ \\
\hline Four affected sibs & 1 \\
\hline Affected sib trios & 2 \\
\hline Affected sib pairs & 23 \\
\hline Affected half-sibs & 33 \\
\hline Children with inhalant allergic sensitization & $109(79.0 \%$ of all children $)$ \\
\hline Four affected sibs & 3 \\
\hline Affected sib trios & 3 \\
\hline Affected sib pairs & 30 \\
\hline Affected half-sibs & 28 \\
\hline Food-sensitized children & 77 (55.8\% of all children) \\
\hline Affected sib trios & 2 \\
\hline Affected sib pairs & 20 \\
\hline Affected half-sibs & 31 \\
\hline Children with allergic asthma & 37 (26.8\% of all children) \\
\hline Affected sib pairs & 6 \\
\hline Affected half-sibs & 25 \\
\hline Children with allergic rhinitis & 87 (63.0\% of all children) \\
\hline Four affected sibs & 2 \\
\hline Affected sib pairs & 23 \\
\hline Affected half-sibs & 33 \\
\hline Children with atopic dermatitis & 39 (28.3\% of al children) \\
\hline Affected sib pairs & 8 \\
\hline Affected half-sibs & 23 \\
\hline
\end{tabular}

herbatum, m1-Penicillium notatum), animals (e3-horse, e2-dog, e1-cat), mites (d2-Dermatophagoides farinae, d1-Dermatophagoides pteronyssinus), weeds (w9Plantago lanceolata, w6-Artemisia vulgaris, w1Ambrosia elatior), trees (t7-Quercus alba, t4-Corylus avellana, $\mathrm{t} 3$-Betula verrucosa, $\mathrm{t} 2$-Alnus incana), and grasses (g12-Secale cereale, g6-Phleum pratense, g3Dactylis glomerata, g1-Anthoxantum odoratum) was measured by inhalation test system. We also measured reactivity to celery (f85), potato (f35), almond (f20), hazelnut (f17), and rice (f9). The inhalant and food atopy were defined as sensitization to at least one of the tested inhalant and food allergens, respectively.
Genetic markers

For the analysis, 19 STR markers located at different chromosomes/chromosomal regions were selected (Table 1) from the National Centre for Biotechnology Information (NCBI) database (http://www.ncbi.nih.gov). The STR markers are characterized in the Marshfield genetic map and show high heterozygosity. All markers, with the exception of the markers on chromosome 8 (D8S1828, D8S285, and D8S1816), are located in atopy candidate regions previously described in genome-wide studies of atopy and/or asthma (Daniels et al. 1996; Wjst et al. 1999; Ober et al. 2000; Xu et al. 2000; Yokouchi et al. 2000, 
2002; Laitinen et al. 2001; Shugart et al. 2001; Haagerup et al. 2002; Koppelman et al. 2002; Altmüller et al. 2005; Ferreira et al. 2005; Kurz et al. 2005) by other groups. Markers selected in regions 2q14.3 (Allen et al. 2003), 5q31.1 (Koppelman et al. 2002), 5q33.3 (Yokouchi et al. 2000), 6p21 (Wjst et al. 1999), 7p14.1 (Daniels et al. 1996, Laitinen et al. 2001; Shugart et al. 2001), 7q22.1 (Xu et al. 2000), 12q21.31 (Nickel et al. 1997), 16q23.2 (Ober et al. 2000), and 19q13.32 (Venanzi et al. 2001) were exactly those that exhibited linkage or, in region 11q12 (Adra et al. 1999), were located in close proximity. Chromosome 12q harbors multiple genetic loci related to asthma and asthmarelated phenotypes including atopy, distinct peaks of linkage being observed in different populations (Raby et al. 2003). Markers in regions $12 \mathrm{q} 13$ and $12 \mathrm{q} 24$ were selected in positions that would enable to test presence of these linkages in the studied population. Similar approach was used in the selection of marker in 16q21 in the vicinity of linkages detected by (Daniels et al. 1996) and (Kurz et al. 2005). In tests of 13q14 and 20p13, we selected the nearest STR marker to the genes PHF11 (Zhang et al. 2003) and $A D A M 33$ (van Eerdewegh et al. 2002), respectively.

Markers on chromosome 8q12 (D8S1828, D8S285, and D8S1816) were chosen on the basis of our previous whole genome search for IgE-controlling loci in mouse (Badalová et al. 2002). The mouse locus $\operatorname{Lmr} 9$ (represented by marker D4Mit149) was mapped to the centromeric part of the mouse chromosome 4 with the most likely and maximal lengths 3.58 and $9.32 \mathrm{Mb}$, respectively, and was shown to have linkage with IgE level (Badalová et al. 2002). The region homologous to the mouse $\operatorname{Lmr} 9$ is located on human chromosome $8 \mathrm{q} 12$ (NCBI database), and the markers D8S1828, D8S285, and D8S1816 were chosen for the search for IgE-controlling loci in human. There is no LD between the regions carrying the three STRs (UCSC Genome Browser Assembly March 2006).

\section{Genotyping}

The primer sequences were obtained from the NCBI database. We used Cy5 carbocyanine dye 5'-end-labeled forward primers and unlabeled reverse primers synthesized by Generi-Biotech s.r.o. (Hradec Králové, Czech Republic) or Sigma-Genosys, (Steinheim, Germany). DNA was amplified in a $10-\mu l$ polymerase chain reaction (PCR) reaction with $10 \mathrm{pmol} / \mu \mathrm{l}$ of forward and reverse primer, $0.2 \mathrm{mM}$ concentration of each dNTP, 1.5 or $2.0 \mathrm{mM} \mathrm{MgCl} 2$ (optimized for each STR), $50 \mathrm{mM} \mathrm{KCl}, 20 \mathrm{mM}$ Tris- $\mathrm{HCl}$ ( $\mathrm{pH}$ 8.4), and $0.1 \mathrm{U}$ of $\mathrm{Taq}$ polymerase, recombinant (GIBCO, Grand Island, NY, USA) and $5 \mathrm{ng} / \mu \mathrm{l}$ of template DNA. The PCR reaction was performed on $0.2 \mathrm{ml}$ nonskirted 96-well U-bottom microtiter plate (ABgene, Epsom,
UK) by MJ Research Thermal Cycler PTC 100 model 96 (MJ Research, Watertown, MA, USA). The universal program was used for DNA amplification: an initial hot start $5 \mathrm{~min}$ at $94^{\circ} \mathrm{C}$, followed by 39 cycles of $94^{\circ} \mathrm{C}$ for $20 \mathrm{~s}$ for denaturing, $55^{\circ} \mathrm{C}$ for $20 \mathrm{~s}$ for annealing, $74^{\circ} \mathrm{C}$ for $20 \mathrm{~s}$ for elongation, and finally $10 \mathrm{~min}$ at $72^{\circ} \mathrm{C}$ for final extension. PCR products $(0.25 \mu \mathrm{l})$ were separated by $\mathrm{CEQ}^{\mathrm{TM}} 8800$ Genetic Analysis System (Beckman Coulter, Fullerton, CA, USA). All inconclusive genotypes were excluded (less than $2.2 \%$ for each marker).

\section{Statistical analysis}

The statistical analysis included all family members (also probands) regardless of affected status. Two different approaches were used for statistical analysis of data. The first approach included non-parametric linkage analysis for co-segregation of a chromosomal region and a trait of interest (qualitative and quantitative). The analysis is based on the calculation of LOD score using the linear model of Kong and Cox (1997). This method allows using small nuclear families and calculation of linkage without assuming the normal distribution of the studied trait. We used the Whittemore and Halpern NPL pair statistics (Whittemore and Halpern 1994) to test for allele sharing among affected individuals. The computer program MERLIN version 1.0.0-@ 2000-2005 (Abecasis et al. 2002) was used for the calculation of identical-by-descent, allele frequencies (across all individuals), and LOD scores.

The second approach used association analysis for QTDT. The general model of QTDT described by Abecasis et al. $(2000 \mathrm{a}, \mathrm{b})$ is applicable to the analysis of quantitative or discrete traits in nuclear families of any size and optionally uses parental phenotypes. We used the orthogonal model (Abecasis et al. 2002) to perform the association analysis of the markers as well as their allelic variants with total and specific IgEs. Calculation was conducted by QTDT program version 2.4.6-(C) 1998-2004 (Abecasis et al. 2000b). Permutation framework (100,000 permutations) provided by QTDT program was used to obtain global $P$ values. These were subsequently corrected for multiple testing by Bonferroni correction for number of tested markers and numbers of alleles of the tested markers.

Sex and age were chosen as covariates in both nonparametric linkage and linkage disequilibrium analysis of the total and specific IgEs and inhalant and food atopy. Correlation between phenotypes (sensitization to different allergens) was estimated by the nonparametric Spearman's correlation analysis using STATISTICA for Windows version 8.0 (StatSoft 1984-2008, Tulsa, OK, USA). 


\section{Results}

$8 \mathrm{q} 12$ is the human genetic homologue of the IgE-controling mouse locus $\operatorname{Lm} 9$

Marker D8S285, located in the human homologue of $\operatorname{Lmr} 9$, showed a suggestive linkage with IgE to P. lanceolata (w9) allergen $(\mathrm{LOD}=2.42, P=0.0004)$ and with a composite phenotype-inhalant allergic sensitization $(\mathrm{LOD}=2.11$, $P=0.0009$; Table 3 ). The locus $8 \mathrm{q} 12$ has not been previously reported in connection with atopy in humans. Potential linkage with LOD $>1$ was also suggested to specific IgE against moulds (A. fumigatus - $\mathrm{m} 3$ and $C$. herbatum$\mathrm{m} 2$ ), animal origin allergens (dog-e2 and cat-e1), mites (D. farinae- $\mathrm{d} 2$ and D. pteronyssinus- $\mathrm{d} 1)$, A. elatior (w1), and potato (f35) allergens (Table 3). The association QTDT analysis of the D8S285 with IgE to P. lanceolata (w9) revealed association with the marker $(P=0.0317)$ and with the certain alleles of the marker (allele $112 \mathrm{bp} P=0.0056$ and allele $114 \mathrm{bp} P=0.0184$ ), supporting the linkage and suggesting that a gene controlling atopy in humans is localized close to D8S285. However, we did not find the significant association after adjusting for number of comparisons by Bonferroni correction.

We found also some evidence of linkage to the markers D8S1828 and D8S116 on chromosome 8q12 that are flanking D8S285. D8S1828 that is located $260 \mathrm{~Kb}$ centromerically from the marker D8S285 exhibited potential linkage with alder allergens $(A$. incana- $\mathrm{t} 2 ; \mathrm{LOD}=1.16$, $P=0.011)$ and with allergen of cultivated rye $(S$. cerealeg12; $\mathrm{LOD}=1.11, P=0.012)$. The marker D8S116, located $300 \mathrm{~Kb}$ telomerically from the marker D8S285, showed a weak linkage with allergens of cultivated rye $(\mathrm{LOD}=0.68$, $P=0.04)$.

Testing of previously reported atopy-controlling regions in the Czech population

We also tested STR markers at the human chromosomal regions that were previously described in genome-wide studies to control atopy in order to determine whether these genetic loci influence $\operatorname{IgE}$ level in the Czech population (Table 1).

Two loci on chromosomes $13 q 14$ and $5 q 33.3$ showed the strongest linkages with IgE to plant allergens (Table 3). We found a suggestive linkage of marker D13S165 (Zhang et al. 2003) with $\operatorname{IgE}$ to $A$. elatior (w1) allergen (LOD= 2.74, $P=0.0002$ ). We also detected a suggestive linkage for marker D5S1507 (Yokouchi et al. 2000) with IgE to $S$. cereale $(\mathrm{g} 12 ; \mathrm{LOD}=2.11, P=0.0009)$. Finally, markers on chromosomes 7p14.1 (D7S2250; Daniels et al. 1996;
Laitinen et al. 2001; Shugart et al. 2001) and 12q13 (D12S1298; Barnes et al. 1996) were found by QTDT assay to be significantly associated with $P$. lanceolata (w9; marker D7S2250, corrected $P=0.026$; allele $147 \mathrm{bp}$ of marker D7S2250, corrected $P=0.034$ ) and $A$. vulgaris (w6; allele $199 \mathrm{bp}$ of marker D12S1298, corrected $P=$ $0.043)$, respectively.

Thus, two markers (D13S165 and D5D1507) were found to have suggestive linkages, and markers D7S2250 and D12S1298 were significantly associated with a number of specific IgEs (Table 3). These data support the results that have been previously published by others (see references in Table 1 and in "Introduction").

There was also some evidence for linkage (LOD $>1$ ) with a number of inhalant and food allergens to the markers D5S816 (5q31.1), D12S1059 (12q22), D16S3253 (16q21), and D20S473 (20p13; Table 3). We did not find any association with and any linkage exceeding the level of a LOD $>1$ to the markers D2S308 (2q14.3), D6S291 (6p21), D7S821 (7q22.1), D11S2006 (11q12), D12S379 (12q21.31), D12S1282 (12q24.31), D16S539 (16q23.2), and D19S601 (19q13.32).

No significant linkage was found with asthma, rhinitis, dermatitis, and total IgE. Markers D19S601 (LOD=0.70, $P=0.04), \mathrm{D} 16 \mathrm{~S} 539$ (LOD=0.69, $P=0.04), \mathrm{D} 7 \mathrm{~S} 2250$ (LOD= $0.83, P=0.03$ ), and D8S285 (LOD=0.38, $P=0.09)$ showed the highest LOD score with asthma, rhinitis, dermatitis, and total IgE, respectively.

\section{Discussion}

Although several genome-wide linkage studies of $\operatorname{IgE}$ controlling loci in humans were conducted, our data for the first time indicate a locus on chromosome 8q12 that could influence development of atopy. The finding of this linkage shows the precision and predictive power of mouse models in investigation of the complex traits in humans.

There are no obvious candidate genes in 8q12 chromosomal region. In the near proximity of the marker D8S285 are localized two oncogenes: MOS (V-MOS Moloney murine sarcoma viral oncogene homolog) and PLAG1 (Pleiomorphic adenoma gene 1). MOS exerts many cellular functions; however, its described impact on B cell functions is limited to B cell malignancies caused by chromosomal translocations of this chromosomal segment (Kirsch et al. 1982). PLAG1 encodes a developmentally regulated, SUMOylated, and phosphorylated zinc finger transcription factor which recognizes a specific bipartite DNA consensus sequence regulating expression of a spectrum of target genes (Van Dyck et al. 2007). One of the target genes of 
Table 3 Specific IgE-controlling loci in the Czech atopic families

\begin{tabular}{|c|c|c|c|c|c|c|}
\hline \multirow[t]{2}{*}{ Locus } & \multirow[t]{2}{*}{ cM (Marshfield) } & \multirow[t]{2}{*}{ Marker } & \multirow[t]{2}{*}{$\mathrm{LOD}_{\mathrm{a}} / \mathrm{P}$ level } & \multicolumn{2}{|c|}{ Association (corrected $P$ level $^{\mathrm{b}}$ ) } & \multirow[t]{2}{*}{ Allergen-specific $\operatorname{IgE}^{\mathrm{e}}$} \\
\hline & & & & Marker $_{\mathrm{c}}$ & Alleles $_{\mathrm{d}}$ & \\
\hline $5 \mathrm{q} 31.1$ & 139.33 & D5S816 & $\begin{array}{l}1.77 / 0.002 \\
1.35 / 0.006 \\
1.27 / 0.008\end{array}$ & & & $\begin{array}{l}\text { g12-Cultivated rye } \\
\text { g3 - Cock's foot } \\
\text { g1-Sweet vernal grass }\end{array}$ \\
\hline $5 q 33.3$ & 157.57 & D5S1507 & $\begin{array}{l}1.17 / 0.01 \\
\mathbf{2 . 1 1 / 0 . 0 0 0 9} \\
1.47 / 0.005 \\
1.41 / 0.005 \\
1.95 / 0.0014\end{array}$ & & & $\begin{array}{l}\text { w9-Plantain } \\
\text { g12-Cultivated rye } \\
\text { g6-Timothy grass } \\
\text { g3 - cock's foot } \\
\text { g1-Sweet vernal grass }\end{array}$ \\
\hline $7 \mathrm{p} 14.1$ & 54.65 & $\mathrm{D} 7 \mathrm{~S} 2250$ & & 0.026 & $147 \mathrm{bp} / 0.034$ & w9-Plantain \\
\hline $8 \mathrm{q} 12$ & 71.0 & D8S1828 & $\begin{array}{l}1.16 / 0.011 \\
1.11 / 0.012\end{array}$ & & & $\begin{array}{l}\text { t2-Alder } \\
\text { g12-Cultivated rye }\end{array}$ \\
\hline $8 \mathrm{q} 12$ & 71.0 & D8S285 & $\begin{array}{l}\mathbf{2 . 1 1 / 0 . 0 0 0 9} \\
1.22 / 0.009 \\
1.36 / 0.006 \\
1.11 / 0.012 \\
1.21 / 0.009 \\
1.05 / 0.014 \\
1.04 / 0.014 \\
\mathbf{2 . 4 2 / 0 . 0 0 0 4} \\
1.14 / 0.011 \\
1.59 / 0.003\end{array}$ & & & $\begin{array}{l}\text { Inhalant atopy }{ }^{\mathrm{f}} \\
\mathrm{m} 3 \text {-Mould } \\
\mathrm{m} 2 \text {-Mould } \\
\text { e2-Dog } \\
\text { e1-Cat } \\
\text { d2-Dust mite } \\
\text { d1-Dust mite } \\
\text { w9-Plantain } \\
\text { w1-Common ragweed } \\
\text { f35-Potato }\end{array}$ \\
\hline $12 \mathrm{q} 13$ & 75.17 & D12S1298 & & & $199 \mathrm{bp} / 0.043$ & w6-Mugwort \\
\hline $12 q 22$ & 105.18 & D12S1059 & $\begin{array}{l}1.12 / 0.012 \\
1.00 / 0.02\end{array}$ & & & $\begin{array}{l}\text { e1-Cat } \\
\text { f20-Almond }\end{array}$ \\
\hline $13 q 14$ & 45.55 & D13S165 & $\begin{array}{l}1.80 / 0.002 \\
\mathbf{2 . 7 4 / 0 . 0 0 0 2}\end{array}$ & & & $\begin{array}{l}\text { w9-Plantain } \\
\text { w1-Common ragweed }\end{array}$ \\
\hline $16 \mathrm{q} 21$ & 71.77 & D16S3253 & $\begin{array}{l}1.33 / 0.007 \\
1.32 / 0.007 \\
1.72 / 0.002\end{array}$ & & & $\begin{array}{l}\text { Inhalant atopy }{ }^{\mathrm{f}} \\
\text { Food atopy } \\
\text { g3-Cock's foot }\end{array}$ \\
\hline $20 \mathrm{p} 13$ & 9.53 & D20S473 & $1.30 / 0.007$ & & & e3-Horse \\
\hline
\end{tabular}

${ }^{\text {a }}$ Only LOD scores $>1.0$ are shown, LOD scores $>2$ are shown in bold

${ }^{\mathrm{b}} P$ values obtained by QTDT program were corrected by Bonferroni correction (see "Materials and methods")

${ }^{\mathrm{c}}$ Association with markers

${ }^{\mathrm{d}}$ Association with specific allele(s)

"Phenotype is described in detail in "Materials and methods"

${ }^{\mathrm{f}}$ Phenotypes of inhalant and food atopy are defined as sensitization to at least one of the inhalant and food allergens, respectively

PLAG1 is insulin-like growth factor-2 (IGF2; Van Dyck et al. 2007), which has pleiotropic functions in immunity. It was shown that $\mathrm{Igf2}^{-/}$mice had decreased numbers of $\mathrm{B} 220^{+}$dendritic cells in spleen (Hansenne et al. 2006). Adoptive transfer of dendritic B220 cells from allergic mice induces specific immunoglobulin $\mathrm{E}$ antibody against food allergens in naïve recipients (Chambers et al. 2004), thus showing possible pathway how could PLAG1 influence atopy.

Another promising target for future research of this locus is LYN kinase gene $(L Y N)$, which is mapped near marker D8S1828 and $150 \mathrm{~Kb}$ proximally of the marker D8S285. The Src tyrosine kinase Lyn is an important modulator in the high affinity receptor for IgE (FceRI) signaling (reviewed in Rivera and Olivera 2007). Lyn-deficient mice exhibit increased serum levels of IgE, increased numbers of mast cells, increased expression of FcERI on mast cells, and other allergy-associated traits (Odom et al. 2004). Although the etiology of the allergy-like phenotype of Lyn deficiency is not completely understood, the regulatory role of Lyn kinase in the development of allergy is strongly indicated by these results. Further, dense SNP coverage, fine mapping, expression studies, and re-sequencing of the $8 \mathrm{q} 12$ region are required to define the gene(s) affecting disease susceptibility.

In pooled groups of Caucasian families recruited from Minnesota and from 11 clinical centers in Europe, Australia, and USA, a suggestive linkage was detected with total serum IgE with a peak of linkage near the marker D8S2324 (94.08 cM-Marshfield; Webb et al. 2007). This 
marker is located outside the $<9 \mathrm{Mb}$ region homologous to mouse IgE-controlling locus $L m r 9$ (Fig. 1), and also $23 \mathrm{cM}$ distally, and therefore is distinct from the locus at $8 \mathrm{q} 12$ described here. These data suggest that two loci controlling human IgE might be localized on chromosome 8q.

Linkage of locus 13q14 with atopy was initially detected in atopic families from Busselton, Western Australia (Daniels et al. 1996). Subsequent association mapping using dense SNP map of this region postulated PDH finger protein 11 gene (PHF11) as a gene predisposing to atopy (Zhang et al. 2003). In our study, the marker D13S165 that maps within $1 \mathrm{~Kb}$ from PHF11 gene is linked to IgE to $A$. elatior (w1; Table 3), suggesting the effect of this gene on $\mathrm{IgE}$ regulation in the Czech atopic patients.

Chromosomal region 5q31-33 seems to be one of the most attractive targets for the investigation of the $\operatorname{IgE}$ control in humans. This region encompasses a cluster of pro-inflammatory cytokine genes $[I L-4, I L-5, I L-9, I L-13$, $I R F-1$ (interferon releasing factor 1) and CSF-1R (receptor for colony stimulating factor 1], the protein products of which are directly involved in immune regulation. The linkage to this locus was corroborated in multiple studies (Marsh et al. 1994; Ober et al. 2000; Xu et al. 2000; Haagerup et al. 2002; Koppelman et al. 2002; Yokouchi et al. 2002). This locus also contains genes TIM1/HAVCR/ KIM1 (5q33.2) and TIM3 (5q33.3) that were shown to control asthma and airway hyperreactivity (McIntire et al. 2001). In the present study, a marker on chromosome $5 q 33.3$ (D5S1507) had a suggestive linkage with IgE to allergens of $S$. cereale (g12) and showed a potential linkage to allergens of Phleum pretense (g6), D. glomerata (g3), and A. odoratum (g1; Table 3). All grass sensitization phenotypes (g12, g6, g3, and g1) showed very high positive correlation with each other $(R=0.937-0.988)$ and therefore showed very similar LOD scores with D5S1507.

QTDT analysis also revealed two atopy-associated markers on chromosomes 7p14.1 (D7S2250) and 12q13 (D12S1298) that did not show genetic linkage with atopy phenotype. Linkage and QTDT association analysis [Kong and Cox linear model (Kong and Cox 1997) and Abecasis orthogonal model (Abecasis et al. 2000a, b), respectively] exploit two different aspects of genetic information. Thus, the results of association and linkage analysis may, but need not, coincide (Wills-Karp and Ewart 2004).

Remarkably, none of the loci showed a significant linkage or association with total IgE. This might be partly due to a high overall sensitization of Czech atopic families that reached nearly $90 \%$ in both parents and offspring. However, we observed that various types of the specific IgE were controlled by different genetic loci. Thus, sensitization to different allergens seems to be determined by different genes. This might also partly explain differences in results obtained by different laboratories that postulated loci controlling total IgE in humans (Hoffjan and Ober 2002).

We did not find any linkage or association with asthma, rhinitis, and dermatitis. This is probably due to the low number of affected sib pairs with asthma and dermatitis in the tested sample (please see details in "Materials and methods", Table 2). Moreover, asthma (Hoffjan and Ober 2002), and probably also rhinitis and dermatitis, may comprise groups of several disorders. In the mouse model, the various components of the pathogenetic pathway of allergic asthma are under separate genetic control (Piavaux et al. 2007); this may explain why in this and other similar studies, asthma is not necessarily linked to the genes that control one out of the multiple sets of pathogenetic components. The analysis of less complex and more exactly defined phenotypes such as levels of total and specific IgE is therefore an important part of genetics of atopic diseases.

The present work demonstrates the power of the genome-wide screening in mice in finding new loci determining complex traits such as IgE levels in humans. Using this approach, a new IgE-controlling locus has been identified on chromosome $8 \mathrm{q} 12$ that influences the sensitization to a number of allergens. Our data also confirm the role of the previously reported loci 13q14, 5q33.3, 7p14.1, and $12 \mathrm{q} 13$ in control of IgE and development of atopy.

Acknowledgments We acknowledge the help of E. Antošová, MD, A. Voříšková, H. Vávrová, MD, E. Vernerová, MD, M. Heroldová, MD, M. Cvačková, MD (University Hospital Royal Vinyards, Prague), E. Škvorová, MD, D. Mudruňková, MD (Department of Immunology and Microbiology, Institute of Public Health, Ústí nad Labem), and M. Zemanová, MD (Allergology practice, Trutnov) and many other clinical specialists involved in recruitment, interviews and clinical description of patients. Most importantly, we thank all the patients without whom this study would have been impossible to undertake. We thank Prof. Peter Demant, MD, PhD, Roswell Park Cancer Institute, Buffalo, U.S.A., and Jasper Manning Jr., M.Sc., Institute of Molecular Genetics, Academy of Sciences of the Czech Republic, Prague, Czech Republic for critical reading of the manuscript and useful suggestions. This investigation was supported by the European Commission (INTAS Genomics 05-10000047761), the Grant Agency of the Czech Republic (grant 310/06/1745), Academy of Sciences of the Czech Republic (program grant AVOZ50520514), Ministry of Education of the Czech Republic (program grant LC06009) and by Research Theme MSM0021620812.

Open Access This article is distributed under the terms of the Creative Commons Attribution Noncommercial License which permits any noncommercial use, distribution, and reproduction in any medium, provided the original author(s) and source are credited.

\section{References}

Abecasis GR, Cardon LR, Cookson WOC (2000a) A general test of association for quantitative traits in nuclear families. Am J Hum Genet 66:279-292. doi:10.1086/302698 
Abecasis GR, Cookson WOC, Cardon LR (2000b) Pedigree tests of transmission disequilibrium. Eur J Hum Genet 8:545-551. doi:10.1038/sj.ejhg.5200494

Abecasis GR, Cherny SS, Cookson WO, Cardon LR (2002) Merlinrapid analysis of dense genetic maps using sparse gene flow trees. Nat Genet 30:97-101. doi:10.1038/ng786

Adra CN, Mao XQ, Kawada H, Gao PS, Korzycka B, Donate JL, Shaldon SR, Coull P, Dubowitz M, Enomoto T, Ozawa A, Syed SA, Horiuchi T, Khaeraja R, Khan R, Lin SR, Flinter F, Beales P, Hagihara A, Inoko $\mathrm{H}$ et al (1999) Chromosome 11q13 and atopic asthma. Clin Genet 55:431-437. doi:10.1034/j.1399-0004.1999.550606.x

Allen M, Heinzmann A, Noguchi E, Abecasis G, Broxholme J, Ponting CP, Bhattacharyya S, Tinsley J, Zhang Y, Holt R, Jones EY, Lench N, Carey A, Jones H, Dickens NJ, Dimon C, Nicholls R, Baker C, Xue L, Townsend E et al (2003) Positional cloning of a novel gene influencing asthma from chromosome $2 \mathrm{q} 14$. Nat Genet 35:258-263. doi:10.1038/ng1256

Altmüller J, Seidel C, Lee YA, Loesgen S, Bulle D, Friedrichs F, Jellouschek H, Kelber J, Keller A, Schuster A, Silbermann M, Wahlen W, Wolff P, Schlenvoigt G, Rüschendorf F, Nürnberg P, Wjst M (2005) Phenotypic and genetic heterogeneity in a genome-wide linkage study of asthma families. BMC Pulm Med 5:1. doi:10.1186/1471-2466-5-1

Badalová J, Svobodová M, Havelková $\mathrm{H}$, Vladimirov V, Vojtíšková J, Engová J, Pilčik T, Volf P, Demant P, Lipoldová M (2002) Separation and mapping of multiple genes that control IgE level in Leishmania major infected mice. Genes Immun 3:187-195. doi:10.1038/sj.gene. 6363838

Barnes KC, Neely JD, Duffy DL, Freidhoff LR, Breazeale DR, Schou C, Naidu RP, Levett PN, Renault B, Kucherlapati R, Iozzino S, Ehrlich E, Beaty TH, Marsh DG (1996) Linkage of asthma and total serum $\operatorname{IgE}$ concentration to markers on chromosome 12q: evidence from Afro-Caribbean and Caucasian populations. Genomics 37:41-50. doi:10.1006/geno.1996.0518

Chambers SJ, Bertelli E, Winterbone MS, Regoli M, Man AL, Nicoletti C (2004) Adoptive transfer of dendritic cells from allergic mice induces specific immunoglobulin $\mathrm{E}$ antibody in naïve recipients in absence of antigen challenge without altering the $\mathrm{T}$ helper $1 / \mathrm{T}$ helper 2 balance. Immunology 112:72-79. doi:10.1111/j.1365-2567.2004.01846.x

Daniels SE, Bhattacharrya S, James A, Leaves NI, Young A, Hill MR, Faux JA, Ryan GF, le Söuef PN, Lathrop GM, Musk AW, Cookson WO (1996) A genome-wide search for quantitative trait loci underlying asthma. Nature 383:247-250. doi:10.1038/383247a0

DeBry RW, Seldin MF (1996) Human/mouse homology relationships. Genomics 33:337-351. doi:10.1006/geno.1996.0209

Demant P, Hart AAM (1986) Recombinant congenic strains-a new tool for analyzing genetic traits determined by more than one gene. Immunogenetics 24:416-422. doi:10.1007/BF00377961

Dizier MH, Besse-Schmittler C, Guilloud-Bataille M, Annesi-Maesano I, Boussaha M, Bousquet J, Charpin D, Degioanni A, Gormand F, Grimfeld A, Hochez J, Hyne G, Lockhart A, Luillier-Lacombe M, Matran R, Meunier F, Neukirch F, Pacheco Y, Parent V, Paty E et al (2000) Genome screen for asthma and related phenotypes in the French EGEA study. Am J Respir Crit Care Med 162:1812-1818

Ferreira MA, O'Gorman L, Le Souëf P, Burton PR, Toelle BG, Robertson CF, Visscher PM, Martin NG, Duffy DL (2005) Robust estimation of experimentwise $P$ values applied to a genome scan of multiple asthma traits identifies a new region of significant linkage on chromosome 20q13. Am J Hum Genet 77:1075-1085. doi:10.1086/497997

Haagerup A, Bjerke T, Schiotz PO, Binderup HG, Dahl R, Kruse TA (2002) Asthma and atopy - a total genome scan for susceptibility genes. Allergy 57:680-686. doi:10.1034/j.1398-9995.2002. 23523.x
Hansenne I, Renard-Charlet C, Greimers R, Geenen V (2006) Dendritic cell differentiation and immune tolerance to insulin-related peptides in Igf2-deficient mice. J Immunol 176:4651-4657

Hoffjan S, Ober C (2002) Present status on the genetic studies of asthma. Curr Opin Immunol 14:709-717. doi:10.1016/S0952-7915(02) 00393-X

Howard TD, Postma DS, Hawkins GA, Koppelman GH, Zheng SL, Wysong AK, Meyers DA, Bleecker ER (2002) Fine mapping of an IgE-controlling gene on chromosome $2 \mathrm{q}$ : analysis of CTLA4 and CD28. J Allergy Clin Immunol 110:743-751. doi:10.1067/ mai.2002.128723

Johansson SG, Hourihane JO, Bousquet J, Bruijnzeel-Koomen C, Dreborg S, Haahtela T, Kowalski ML, Mygind N, Ring J, van Cauwenberge P, van Hage-Hamsten M, Wüthrich B, EAACI (the European Academy of Allergology and Cinical Immunology) nomenclature task force (2001) A revised nomenclature for allergy. An EAACI position statement from the EAACI nomenclature task force. Allergy 56:813-824. doi:10.1034/j.13989995.2001.t01-1-00001.x

Kirsch IR, Morton CC, Nakahara K, Leder P (1982) Human immunoglobulin heavy chain genes map to a region of translocations in malignant B lymphocytes. Science 216:301-303. doi:10.1126/science.6801764

Kong A, Cox NJ (1997) Allele-sharing models: LOD scores and accurate linkage tests. Am J Hum Genet 61:1179-1188. doi: $10.1086 / 301592$

Koppelman GH, Stine OC, Xu J, Howard TD, Zheng SL, Kauffman HF, Bleecker ER, Meyers DA, Postma DS (2002) Genome-wide search for atopy susceptibility genes in Dutch families with asthma. J Allergy Clin Immunol 109:498-506. doi:10.1067/ mai.2002.122235

Kurz T, Altmüller J, Strauch K, Rüschendorf F, Heinzmann A, Moffatt MF, Cookson WO, Inacio F, Nürnberg P, Stassen $\mathrm{HH}$, Deichmann KA (2005) A genome-wide screen on the genetics of atopy in a multiethnic European population reveals a major atopy locus on chromosome 3q21.3. Allergy 60:192-199. doi:10.1111/j.1398-9995.2005.00646.x

Laitinen T, Daly MJ, Rioux JD, Kauppi P, Laprise C, Petäys T, Green T, Cargill M, Haahtela T, Lander ES, Laitinen LA, Hudson TJ, Kere J (2001) A susceptibility locus for asthma-related traits on chromosome 7 revealed by genome-wide scan in a founder population. Nat Genet 28:87-91. doi:10.1038/88319

Laitinen T, Polvi A, Rydman P, Vendelin J, Pulkkinen V, Salmikangas P, Mäkelä S, Rehn M, Pirskanen A, Rautanen A, Zucchelli M, Gullstén H, Leino M, Alenius H, Petäys T, Haahtela T, Laitinen A, Laprise C, Hudson TJ, Laitinen LA et al (2004) Characterization of a common susceptibility locus for asthma-related traits. Science 304:300-304. doi:10.1126/science. 1090010

Lander ES, Schork NJ (1994) Genetic dissection of complex traits. Science 265:2037-2048. doi:10.1126/science.8091226

Lipoldová M, Svobodová M, Krulová M, Havelková H, Badalová J, Nohýnková E, Holáň V, Hart AA, Volf P, Demant P (2000) Susceptibility to Leishmania major infection in mice: multiple loci and heterogeneity of immunopathological phenotypes. Genes Immun 1:200-206. doi:10.1038/sj.gene.6363660

Lipoldová M, Demant P (2006) Genetic susceptibility to infectious disease: lessons from mouse models of leishmaniasis. Nat Rev Genet 7:294-305. doi:10.1038/nrg1832

Marsh DG, Neely JD, Breazeale DR, Ghosh B, Freidhoff LR, EhrlichKautzky E, Schou C, Krishnaswamy G, Beaty TH (1994) Linkage analysis of IL4 and other chromosome 5q31.1 markers and total serum immunoglobulin E concentrations. Science 264:1152-1156. doi:10.1126/science. 8178175

McIntire JJ, Umetsu SE, Akbari O, Potter M, Kuchroo VK, Barsh GS, Freeman GJ, Umetsu DT, DeKruyff RH (2001) Identification of 
Tapr (an airway hyperreactivity regulatory locus) and the linked Tim gene family. Nat Immunol 2:1109-1116. doi:10.1038/ni739

Moffatt MF, Kabesch M, Liang L, Dixon AL, Strachan D, Heath S, Depner M, von Berg A, Bufe A, Rietschel E, Heinzmann A, Simma B, Frischer T, Willis-Owen SA, Wong KC, Illig T, Vogelberg C, Weiland SK, von Mutius E, Abecasis GR et al (2007) Genetic variants regulating ORMDL3 expression contribute to the risk of childhood asthma. Nature 448:470-473. doi:10.1038/ nature 06014

Nickel R, Wahn U, Hizawa N, Maestri N, Duffy DL, Barnes KC, Beyer K, Forster J, Bergmann R, Zepp F, Wahn V, Marsh DG (1997) Evidence for linkage of chromosome 12q15-q24.1 markers to high total serum IgE concentrations in children of the German Multicenter Allergy Study. Genomics 46:159-162. doi:10.1006/geno.1997.5013

Ober C, Tsalenko A, Parry R, Cox NJ (2000) A second-generation genomewide screen for asthma-susceptibility alleles in a founder population. Am J Hum Genet 67:1154-1162

Ober C, Hoffjan S (2006) Asthma genetics 2006: the long and winding road to gene discovery. Genes Immun 7:95-100. doi:10.1038/sj.gene.6364284

Ober C, Tan Z, Sun Y, Possick JD, Pan L, Nicolae R, Radford S, Parry RR, Heinzmann A, Deichmann KA, Lester LA, Gern JE, Lemanske RF Jr, Nicolae DL, Elias JA, Chupp GL (2008) Effect of variation in CHI3L1 on serum YKL-40 level, risk of asthma, and lung function. N Engl J Med 358:1682-1691. doi:10.1056/ NEJMoa0708801

Odom S, Gomez G, Kovarova M, Furumoto Y, Ryan JJ, Wright HV, Gonzalez-Espinosa C, Hibbs ML, Harder KW, Rivera J (2004) Negative regulation of immunoglobulin E-dependent allergic response by Lyn kinase. J Exp Med 199:1491-1502. doi: $10.1084 /$ jem. 20040382

Piavaux B, Jeurink PV, Groot PC, Hofman GA, Demant P, Van Oosterhout AJ (2007) Mouse genetic model for antigen-induced airway manifestations of asthma. Genes Immun 8:28-34. doi:10.1038/sj.gene.6364354

Raby BA, Silverman EK, Lazarus R, Lange C, Kwiatkowski DJ, Weiss ST (2003) Chromosome 12q harbors multiple genetic loci related to asthma and asthma-related phenotypes. Hum Mol Genet 12:1973-1979. doi:10.1093/hmg/ddg208

Rivera J, Olivera A (2007) Src family kinases and lipid mediators in control of allergic inflammation. Immunol Rev 217:255-268. doi:10.1111/j.1600-065X.2007.00505.x

Shugart YY, Specchia C, Li HH, Doan BQ, Mathias RA, Devoto M (2001) Comparison of sib pair-based approaches for identifying quantitative trait loci underlying asthma in the Busselton families. Genet Epidemiol 1:198-203

Van Dyck F, Declercq J, Braem CV, Van de Ven WJ (2007) PLAG1, the prototype of the PLAG gene family: versatility in tumour development. Int J Oncol 30:765-774 (review)

van Eerdewegh P, Little RD, Dupuis J, Del Mastro RG, Falls K, Simon J, Torrey D, Pandit S, McKenny J, Braunschweiger K, Walsh A, Liu Z, Hayward B, Folz C, Manning SP, Bawa A, Saracino L, Thackston M, Benchekroun Y, Capparell N et al (2002) Association of the ADAM33 gene with asthma and bronchial hyperresponsiveness. Nature 418:426-430. doi:10. 1038/nature00878
Venanzi S, Malerba G, Galavotti R, Lauciello MC, Trabetti E, Zanoni G, Pescollderungg L, Martinati LC, Boner AL, Pignatti PF (2001) Linkage to atopy on chromosome 19 in north-eastern Italian families with allergic asthma. Clin Exp Allergy 31:1220 1224. doi:10.1046/j.1365-2222.2001.01132.x

Vercelli D (2008) Discovering susceptibility genes for asthma and allergy. Nat Rev Immunol 8:169-182. doi:10.1038/nri2257

Webb BT, van den Oord E, Akkari A, Wilton S, Ly T, Duff R, Barnes KC, Carlsen K, Gerritsen J, Lenney W, Silverman M, Sly P, Sundy J, Tsanakas J, von Berg A, Whyte M, Blumenthal M, Vestbo J, Middleton L, Helms PJ et al (2007) Quantitative linkage genome scan for atopy in a large collection of Caucasian families. Hum Genet 121:83-92. doi:10.1007/s00439-006-0285-Z

Whittaker PA (2003) What is the relevance of bioinformatics to pharmacology? Trends Pharmacol Sci 24:434-439. doi:10.1016/ S0165-6147(03)00197-4

Whittemore AS, Halpern J (1994) A class of tests for linkage using affected pedigree members. Biometrics 50:118-127. doi:10.2307/ 2533202

Wills-Karp M, Ewart SL (2004) Time to draw breath: asthmasusceptibility genes are identified. Nat Rev Genet 5:376-387. doi: $10.1038 / \operatorname{nrg} 1326$

Wjst M, Fischer G, Immervoll T, Jung M, Saar K, Rueschendorf F, Reis A, Ulbrecht M, Gomolka M, Weiss EH, Jaeger L, Nickel R, Richter K, Kjellman NIM, Griese M, von Berg A, Gappa M, Riedel F, Boehle M, van Koningsbruggen S et al (1999) A genome-wide search for linkage to asthma. Genomics 58:1-8

Xu J, Postma DS, Howard TD, Koppelman GH, Zheng SL, Stine OC, Bleecker ER, Meyers DA (2000) Major genes regulating total serum immunoglobulin $\mathrm{E}$ in families with asthma. Am J Hum Genet 67:1163-1173. doi: 10.1086/321190

Xu X, Fang Z, Wang B, Chen C, Guang W, Jin Y, Yang J, Lewitzky S, Aelony A, Parker A, Meyer J, Weiss ST, Xu X (2001) A genomewide search for quantitative-trait loci underlying asthma. Am J Hum Genet 69:1271-1277. doi:10.1086/324650

Yokouchi Y, Nukaga Y, Shibasaki M, Noguchi E, Kimura K, Ito S, Nishihara M, Yamakawa-Kobayashi K, Takeda K, Imoto N, Ichikawa K, Matsui A, Hamaguchi H, Arinami T (2000) Significant evidence for linkage of mite-sensitive childhood asthma to chromosome 5q31-q33 near the interleukin 12 B locus by a genome-wide search in Japanese families. Genomics 66:152-160. doi:10.1006/geno.2000.6201

Yokouchi Y, Shibasaki M, Noguchi E, Nakayama J, Ohtsuki T, Kamioka M, Yamakawa-Kobayashi K, Ito S, Takeda K, Ichikawa K, Nukaga Y, Matsui A, Hamaguchi H, Arinami T (2002) A genome-wide linkage analysis of orchard grass-sensitive childhood seasonal allergic rhinitis in Japanese families. Genes Immun 3:9-13. doi:10.1038/sj.gene.6363815

Zhang Y, Leaves NI, Anderson GG, Ponting CP, Broxholme J, Holt R, Edser P, Bhattacharyya S, Dunham A, Adcock IM, Pulleyn L, Barnes PJ, Harper JI, Abecasis G, Cardon L, White M, Burton J, Matthews L, Mott R, Ross M et al (2003) Positional cloning of a quantitative trait locus on chromosome 13q14 that influences immunoglobulin E levels and asthma. Nat Genet 34:181-186. doi:10.1038/ng1166

Zhang J, Paré PD, Sandford AJ (2008) Recent advances in asthma genetics. Respir Res 9:4. doi:10.1186/1465-9921-9-4 